\title{
Effective Weed Management Strategy for Winter Maize (Zea mays L) under Humid Condition of Southern Rajasthan, India
}

\author{
Hargilas* \\ Agricultural Research Station, Maharana Pratap University of Agriculture \& Technology, \\ Banswara, Rajasthan-327 001, India \\ *Corresponding author
}

\begin{tabular}{|l|}
\hline Ke y w o r d s \\
Maize, Yield, \\
Tembotrione, Weed \\
control efficiency, \\
B: C ratio
\end{tabular}

\section{Introduction}

Maize is the third most important cereal after rice and wheat in the world agriculture to provide food, feed and source for numerous industrial products. Maize is the most versatile crop with wider adaptability to grow in varied agro-ecological regions from semi-arid to sub-
A field experiment was conducted during the winter season of 2016-17 and 2017-18 at Agricultural Research Station (MPUAT), Banswara (Rajasthan), India to find out effective weed management strategy for enhancing the economical return of winter maize under humid condition of Southern Rajasthan. Ten treatment combinations of pre-emergence (atrazine), post-emergence (halosulfuron, 2, 4-D, tembotrione and topramezone) herbicides with weed free and weedy check laid out in randomized block design with three replications. Results revealed that pre-emergence application of atrazine $50 \mathrm{WP} @ 0.50 \mathrm{~kg}$ a.i./ha $f b$ post emergence application of tembotrione $42 \mathrm{SC} @ 120 \mathrm{~g}$ a.i./ha at 35 DAS reduced the density of grasses, broad leaves and sedge weeds and improved the growth and yield attributes of the crop. The highest yield (12.65 t/ha) and lowest weed index were recorded with weed free followed by grain yield (12.31 t/ha) and weed index (2.68) of the treatment of atrazine 50 WP @ $0.50 \mathrm{~kg}$ a.i./ha PE fb tembotrione 42 SC @ $120 \mathrm{~g}$ a.i./ha PoE. The highest net return (\$2095/ha) recorded with atrazine PE fb tembotrione PoE followed by weedy free ( $\$ 2011 / \mathrm{ha})$. However, maximum B: C ratio (3.57) recorded with pre-emergence application of atrazine $50 \mathrm{WP} @ 0.50 \mathrm{~kg}$ a.i./ha $\mathrm{fb}$ post-emergence application of tembotrione 42\% SC @ $120 \mathrm{~g} / \mathrm{ha}$ following by tembotrione $42 \mathrm{SC} @ 120 \mathrm{~g}$ a.i./ha PoE alone (3.00), which was significantly higher over rest treatments. Atrazine 50\% WP @ $0.50 \mathrm{~kg}$ a.i./ ha PE $f b$ tembotrione 42 SC @ $120 \mathrm{~g}$ a.i./ha PoE was found best among the herbicidal treatments in all respects. Hence, sequential application of atrazine 50 WP @ 0.50 kg a.i./ha PE fb tembotrione 42 SC @ $120 \mathrm{~g}$ a.i./ha PoE at 35 DAS may be recommended for higher economic return through effective weed management in winter maize under humid condition of Southern Rajasthan. 
$84 / \mathrm{t}$ in the year of $2006-07$ to $\$ 264 / \mathrm{t}$ in the year of 2018-19 led to make maize as a more competitive crop and encouraged farmers to grow maize to a large extent (Anonymous, 2019). Maize (Zea maize L.) is becoming an important crop of winter season due to prevailing mild winters coupled with high irrigation potential in Southern Rajasthan. Despite of small and marginal land holdings, the area under winter maize is increasing in this region due very high realizable yields at the farmer's fields. Winter maize in this area enjoys long duration of 130-150 days with the initial slow growth that allows weeds. Weed infestation is the supreme importance among biotic factors that are responsible for low maize grain yield. Worldwide maize production is hampered up to $40 \%$ by competition from weeds, which are the most important pest group of this crop. Generally, weeds reduce crop yields by competing for light, nutrients, water and carbon dioxide as well as interfering with harvesting and increasing the cost involved in crop production.

Overall, weeds impose the highest loss potential $(37 \%)$, which is higher than the loss potentials due to animal pests (18\%), fungal and bacterial pathogens $(16 \%)$ and viruses (2\%) (Chikoye et al., 2005). Maize is highly suffered by the weeds due to wider spacing and slow initial growth that favours the growth of weeds. Yield losses due to weeds in maize vary from 28 to $93 \%$, depending on the type of weed flora and intensity and duration of crop-weed competition (Sharma and Thakur, 1998). The critical period of cropweed competition in maize was 20-60 days after sowing reported during the winter season (Verma et al., 2009). The practice of repeated hand weeding and inter-culture is still widely adopted, but these practices are more expensive. Chemical control is a better alternative to manual weeding because it is cheaper, faster, and gives better control
(Chikoye et al., 2004). Herbicide like atrazine, pendimethalin, metribuzin, fluchlorin alone or in combination applied as pre-planting, preemergence and 2,4-D applied as postemergence stage was widely evaluated but a single combination was not found uniform effectively. Therefore, this research study carried out to evaluate the effect of new herbicides on weeds, yield and yield component of winter maize under humid condition of Southern Rajasthan.

\section{Materials and Methods}

A research experiment laid out at Agricultural Research Station, Banswara of Maharana Pratap University of Agriculture and Technology, Udaipur during two consecutive winter seasons of 2016-17 and 2017-18. An experimental area is situated in humid Agroclimatic Zone ivb, representing the Southern plains of Rajasthan at $23^{\circ} 33^{\circ} \mathrm{N}$ latitude, $74^{\circ}$ 27'E longitude, and altitude of $220 \mathrm{M}$ above Mean Sea Level. The climate of this region is characterized as subtropical, sub-humid with dry and hot summer and mild winters. The meteorological data during crop seasons (November to April, 2016-17 and 2017-18), for experimental site is presented in Figure 1 and 2. The Experimental soil field was clay loam in texture, slightly alkaline in reaction with low in organic carbon $(0.43 \%)$, low in available nitrogen $246 \mathrm{~kg} / \mathrm{ha}$, medium in available phosphorus (24.2 kg/ha) and high in potassium $(385 \mathrm{~kg} / \mathrm{ha})$. The experimental site was characterized by a double cropping system of soybean followed by winter maize. After soybean harvest, the field was ploughed with the tractor-drowned cultivator to a depth of 15 to $20 \mathrm{~cm}$ and followed by disking and smoothing with a land leveller. The seed of maize hybrid Bio 9681 was dibbled manually at spacing of $60 \times 20 \mathrm{~cm}$ using $25 \mathrm{~kg}$ seed $/ \mathrm{ha}$ in the first fortnight of November, 2016 and 2017. Recommended dose of fertilizers for maize was $150 \mathrm{~kg} \mathrm{~N}, 60 \mathrm{~kg} \mathrm{P}_{2} \mathrm{O}_{5}$ and $40 \mathrm{~kg}$ 
$\mathrm{K}_{2} \mathrm{O} /$ ha. The full dose of phosphorus and potassium was applied through single super phosphate and murate of potash, respectively in line opening by fertilizer drill machine. Nitrogen was applied in 4 split $(25 \%$ as basal, $25 \%$ at $15 \mathrm{DAS}, 25 \%$ at $30 \mathrm{DAS}$ and $25 \%$ at 45 DAS) through urea. Each plot was $5 \mathrm{~m}$ long by $3.0 \mathrm{~m}$ wide and consisted of five maize rows. Ten treatments were comprising of weedy check, weed free, atrazine 50 WP @ $0.5 \mathrm{~kg}$ a.i./ha as PE (pre-emergence), atrazine 50 WP @ 0.50 kg a.i./ha fb 2,4-D amine 58 SL @ 400 a.i./ha as PoE (post emergence) at 35 DAS, halosulfuron 75 WG @60 g a.i./ha as PoE at $35 \mathrm{DAS}$, atrazine $50 \mathrm{WP} @ 0.50 \mathrm{~kg}$ a.i./ha as PE fb halosulfuron 75 WG @60 g a.i./ha as PoE at 35 DAS, tembotrione 42 SC @ $120 \mathrm{~g}$ a.i./ha as PoE at $35 \mathrm{DAS}$, atrazine 50 WP @ $0.5 \mathrm{~kg}$ a.i./ha PE fb tembotrione 42 SC @ $120 \mathrm{~g}$ a.i./ha as PoE at 35 DAS, topramezone 33.6 SC @ $25.2 \mathrm{~g}$ a.i./ha as PoE at 35 DAS and atrazine 50 WP @ $0.50 \mathrm{~kg}$ a.i./ha as PE fb topramezone 33.6 SC @ 25.2 $\mathrm{g}$ a.i./ha as PoE. Weed free and un-weeded control also kept for comparison. Preemergence (PE) application of herbicides was done within 24 hours of sowing and post emergence $(\mathrm{PoE})$ herbicides were applied after 35 days after sowing (DAS).

Herbicides were sprayed using a manual operated Knap-sack sprayer fitted with flat fan nozzle and calibrated to deliver $450 \mathrm{~L} / \mathrm{ha}$ aqueous solution. Phytotoxic effect of herbicides was determined by estimating residual effect on following soybean crop. Other plant protection practices for disease and pest control were also applied to the crop. Five irrigations were applied to maize crop in the winter season, whereas, soybean was raised without irrigation in the rainy season. Soybean was raised in the maize plots without disturbing the original layout. Soybean variety RKS 24 was sown in first fornight of July by using the seed rate of $80 \mathrm{~kg} / \mathrm{ha}$ by seed cum fertilizer drill.

\section{Weed dynamics assessment}

The weed composition of the experimental field included mixture of broad leaved weeds, grasses and perennial sedge (Table 1). Chenopodium album and Parthenium hysterophorus L. were dominant broad leaved weed and Cyperus rotendus and Cynodon datylon were dominant nut and grasses weeds. Convolvulus arvensis, Anagallis arvensis, Melilotus alba, Chenopodium murale, Avena sativa, Phalaris minor were sub-dominant weeds were recorded in weedy check at 60 days after sowing. Most weed flora recorded in this study also reported by Hargilas (2018) in the winter season in clay loam soil of southern Rajasthan. However, it documented that the weed species vary from place to place, soil to soil and season to season. Visual observations at 60 days after sowing of maize crop revealed that twice-manual hand hoeing and weeding at 20 and 40 DAS and one hand weeding at 60 DAS of the crop gave complete control of weeds (100\%). Total weed density reached to highest at 60 DAS and slightly declined thereafter at later growth stages due to early maturity of short duration annual weeds. All the weed control treatments reduced the weed density significantly over the weedy check (Table 2). The lowest weed density was recorded in weed free plot which weeded throughout the crop season and afterwards the lowest total weed density was recorded with pre-emergence application of atrazine 50 WP @ $0.5 \mathrm{~kg}$ a.i./ ha followed by post emergence application of tembotrione 42 SC @ $120 \mathrm{~g}$ a.i./ha at 35 DAS due to effective control of Chenopodium album, Parthenium hysterophorus, Cyperus rotendus and Cynodon datylon which were contributed about $95 \%$ of the total weed population at later stage of crop growth (Table 2). Alone post emergence application of tembotrion 42 SC @ $120 \mathrm{~g}$ a.i./ha at 35 DAS was at par with sequential application of atrazine as $\mathrm{PE} \mathrm{fb}$ tembotrion as POE. Application of atrazine 50 
WP @ $0.5 \mathrm{~kg}$ a.i./ha as PE fb 2,4-D amine 58 SL@ @ $400 \mathrm{~g}$ a.i.ha ${ }^{-1}$ as POE was effectively reduced the broad leaved weed but it not controlled grasses and sedges. Post-emergence of halosulfuron 75 WG @ $60 \mathrm{~g}$ a.i./ha was mostly controlled the sedges only. Postemergence application of topramezone 33.6 SC @ $25.2 \mathrm{~g}$ a.i./ ha was controlled the broad leaved and narrow leaved weed but it escaped sedges. Overall, pre-emergence application of atrazine 50WP @ $0.50 \mathrm{~kg}$ a.i./ ha fb tembotrione 42 SC @ $120 \mathrm{~g}$ a.i./ ha at 35 DAS was controlled maximum weed density of all group of weed. Similar observation reported by Singh and Sheoran (2008).

\section{Weed dry matter accumulation assessment}

At 60 days after sowing of maize, the total weed dry matter was significantly higher in the weedy check plot than treated plots. All the weed control treatments significantly reduced total weed dry accumulation over the weedy check (Table 2). The lowest total weed dry matter accumulation recorded in weedy free plot. Pre-emergence application of atrazine 50 WP @ $0.50 \mathrm{~kg} / \mathrm{ha}$ fb post emergence application of tembotrione 42 SC @ $120 \mathrm{~g}$ a.i./ha was recorded minimum weed dry matter accumulation $\left(20 \mathrm{~g} / \mathrm{m}^{2}\right)$ followed by tembotrione $42 \mathrm{SC} @ 120 \mathrm{~g}$ a.i./ha PoE at 35 DAS alone $\left(45.93 \mathrm{~g} / \mathrm{m}^{2}\right)$, however, it was significantly lower weed dry matter accumulation than rest treatment. Preemergence application of atrazine 50 WP @ $0.50 \mathrm{~kg}$ a.i./ha fb post-emergence application of 2,4-D amine $58 \mathrm{SL} @ 400 \mathrm{~g}$ a.i./ha at 35 DAS was found next best effective treatment that produced lower total weed dry matter accumulation $\left(151.63 \mathrm{~g} / \mathrm{m}^{2}\right)$ followed by atrazine 50 WP @ $0.50 \mathrm{~kg}$ a.i./ha as PE fb halosulfuron75 WG @60 g a.i. /ha as PoE at 35 DAS $\left(152.36 \mathrm{~g} / \mathrm{m}^{2}\right)$ and it also significantly reduced weed dry matter than rest treatment. The pre-emergence application of atrazine 50 WP @ $0.50 \mathrm{~g}$ a.i./ha fb tompromazone 33.6
SC@25.2 g/ha PoE at 35 DAS was significantly lower weed matter accumulation $\left(185 \mathrm{~g} / \mathrm{m}^{2}\right)$ followed by halosulfurone $75 \mathrm{WG}$ @ $60 \mathrm{~g} / \mathrm{m}^{2} \mathrm{PoE}$ at $35 \mathrm{DAS}$ alone $\left(207 \mathrm{~g} / \mathrm{m}^{2}\right)$ than topramezone 33.6 SC@ $25.2 \mathrm{~g}$ a.i./ha PoE at 35 DAS alone $\left(231 \mathrm{~g} / \mathrm{m}^{2}\right)$. Significant variations were observed between the sequencial pre-emergence application of atrazine $\mathrm{fb}$ post emergence application of halosulfuron and topramezone and alone application of halosulfuron and topramezone, respectively. Post emergence application of halosulfuron and topramezone were lesser effective to reduce total weed dry matter accumulation than sequential application followed by atrazine. Pre-emergence application of atrazine was $51.46 \%$ lower total weed dry matter accumulation compared to weedy check $(581 \mathrm{~g} / \mathrm{ha})$. These findings are in accordance with Swetha et al., (2015).

\section{Weed control efficiency}

At 60 DAS, the highest weed control efficiency was recorded in weed free plot that kept weed free through two manual hoeing at 20 and 40 DAS and one hand weeding at 60 DAS, whereas, lowest weed efficiency was recorded in weedy check (Table 2). Among, weed management treatments, pre-emergence application of atrazine 50 WP @ $0.50 \mathrm{~kg}$ a.i./ha $\mathrm{fb}$ post-emergence application of tembotrione 42 SC @ $120 \mathrm{~g}$ a.i./ha at $35 \mathrm{DAS}$ was significantly higher $96.54 \%$ weed control efficiency than rest treatments. Postemergence application of tembotrione $42 \mathrm{SC}$ @ $120 \mathrm{~g}$ a.i./ha alone at 35 DAS was recorded next effective weed control efficiency (92.07\%). Atrazine 50 WP @ 0.50 kg a.i./ha PE fb 2,4-D ester 38 EC @ $500 \mathrm{~g}$ a.i./ha at 35 DAS was $73.81 \%$ controlled total weeds followed by atrazine $50 \mathrm{WP} @ 0.50 \mathrm{~kg}$ a.i./ha $\mathrm{PE}$ fb halosulfuron $75 \mathrm{WG} @ 60 \mathrm{~g}$ a.i./ha PoE at 35 DAS (73.70\%). However, it was significantly superior over rest treatments. Atrazine 50 WP @ $0.50 \mathrm{~kg}$ a.i./ha PE fb 
topramezone 33.6 SC@ 25.2g /ha PoE recorded weed control efficiency $(68.02 \%)$ followed by halosulfuron 75 WP @ $60 \mathrm{~g}$ a.i./ha PoE alone at 35 DAS recorded WCE (64.14\%). Similarly, topramezone 33.6 SC @ $25.2 \mathrm{~g}$ a.i./ha as PoE at 35 DAS alone was $60.15 \%$ controlled total weeds, whereas, preemergence application of atrazine 50 WP @ $0.50 \mathrm{~kg}$ a.i. /ha alone was $51.35 \%$ controlled weeds which was significantly superior over weedy check. Significant variations recorded with the sequential application of preemergence herbicide $\mathrm{fb}$ post emergence herbicides, post-emergence herbicides alone and pre-emergence herbicides alone. Singh et al., (2012) reported similar weed control efficiency of post-emergence application of tembotrione in maize.

\section{Plant growth and yield parameters}

The highest plant height $(283 \mathrm{~cm})$ was recorded in weed free plot which was at par with pre-emergence application of atrazine 50 WP @ $0.50 \mathrm{~kg}$ a.i./ha fb post-emergence application of tembotrione 42 SC @ $120 \mathrm{~g}$ a.i./ha at 35 DAS $(282 \mathrm{~cm})$ followed by alone tembotrion 42 SC @ $120 \mathrm{~g}$ a.i./ha as PoE at 35 DAS $(279 \mathrm{~cm})$ and atrazine 50 WP@ $0.50 \mathrm{~kg}$ a.i./ha PE fb topramezone 33.6 SC @ $25.2 \mathrm{~g}$ a.i./ha PoE $(270 \mathrm{~cm})$ and it was significantly over higher rest treatments (Table 3). Significant variation in plant height was observed between sequential application of atrazine PE fb 2, 4-D ester, halosulfuron and topramazone PoE at $35 \mathrm{DAS}$ and alone post emergence application of 2,4-D ester, halosulfuron and topramezone, respectively. Minimum plant height $(210 \mathrm{~cm})$ was recorded from weedy check plot.

Maximum plant population (83332 plants/ha) was recorded from pre-emergence application of atrazine $50 \mathrm{WP} @ 0.50 \mathrm{~kg}$ a.i./ha fb postemergence application of tembotrione 42 SC @ $120 \mathrm{~g}$ a.i. /ha at 35 DAS which was at par with weed free plot followed by tembotrione alone and atrazine PE fb 2,4-D ester PoE at 35 DAS, respectively (Table 3). Minimum plant population (55560 plants/ha) was recorded from weedy check followed by halosulfuron PoE alone, topramezone PoE alone and atrazine as $\mathrm{PE} \mathrm{fb}$ topramezone $\mathrm{PoE}$, respectively. The maximum cob $(106,000$ cobs/ha) was recorded in weed free plot followed by pre-emergence application of atrazine 50 WP @ $0.50 \mathrm{~kg}$ a.i./ha at 35 DAS fb post-emergence application of tembotrion 42 SC @ $120 \mathrm{~g}$ a.i./ha, however, it was significantly superior over rest treatments (Table 3). Next more number of cobs $(83,333$ cobs/ha) recorded in post-emergence application of tembotrione 42 SC @ $120 \mathrm{~g}$ a.i./ha alone which was significantly higher over rest treatments. The minimum cobs $(47,222 \mathrm{cobs} / \mathrm{ha})$ was recorded in weedy check plot followed halosulfuron $\mathrm{PoE}$ alone and atrazine $\mathrm{PE} \mathrm{fb}$ halosulfuron PoE. Rest treatments were produced more cobs than halosufuron PoE alone and atrazine $\mathrm{PE} \mathrm{fb}$ halosulfuron PoE.

The maximum number of grains/cob (651) was recorded in weed free plot which was at par with pre-emergence application of atrazine 50 WP @ $0.50 \mathrm{~kg}$ a.i./ha fb post-emergence application of tembotrione 42 SC @ $120 \mathrm{~g}$ a.i./ha (639 grains/cob) and significantly higher than rest treatments (Table 3). Postemergence application of tembotrione 42 SC @ $120 \mathrm{~g}$ a.i./ha at 35 DAS was 554 grains/cob significantly higher than left herbicidal treatments. Pre-emergence application of atrazine 50 WP @ $0.50 \mathrm{~g}$ a.i./ha fb 2,4-D ester 38 EC @ 500 g a.i./ ha was recorded (460 grains/cob) next best treatment which was at par with other herbicidal treatments and significantly higher than weedy check (268 grains/ha), respectively. Martin et al., (2011) reported that yield attributes of sweet corn were higher in the application of attrazine along with tembotrine. 
Table.1 Diverse weed flora in maize during 2016-17 and 2017-18

\begin{tabular}{|l|c|c|}
\hline Grass weeds & Broadleaved weeds & Sedge \\
\hline Cynodon dactylon & Chenopodium album & Cyperus rotundus \\
\hline Avena fatua & Chenopodium murale & \\
\hline Phalaris minor & Parthenium hysterophorus $\mathbf{L}$ & \\
\hline & Anagalis arvensis & \\
\hline & Convolvulus arvensis & \\
\hline & Melilotus album & \\
\hline
\end{tabular}

Table.2 Effect of weed management treatments on weed density, weed dry matter, weeds control efficiency (Pooled data of two years)

\begin{tabular}{|c|c|c|c|c|c|c|c|c|c|c|c|c|}
\hline \multirow[t]{2}{*}{ Treatment } & \multicolumn{4}{|c|}{ Weed density $\left(\mathrm{no} / \mathrm{m}^{2}\right)$} & \multicolumn{4}{|c|}{ Weed dry matter $\left(\mathrm{g} / \mathrm{m}^{2)}\right.$} & \multicolumn{4}{|c|}{ Weed control efficiency $(\%)$} \\
\hline & Grassy & BLW & Sedges & Total & Grassy & BLW & Sedges & Total & Grassy & BLW & Sedges & Total \\
\hline Weedy check & 82.01 & 98.10 & 47.95 & 228.06 & 220.33 & 277.67 & 82.67 & 580.67 & 0.00 & 0.00 & 0.00 & 0.00 \\
\hline Weed free & 0.00 & 0.00 & 0.00 & 0.00 & 0.00 & 0.00 & 0.00 & 0.00 & 100.00 & 100.00 & 100.00 & 100.00 \\
\hline Atrazine 50WP @ 0.5 kg a.i./ha PE & 71.50 & 62.89 & 27.88 & 162.26 & 111.67 & 123.33 & 47.00 & 282.00 & 48.07 & 55.39 & 43.25 & 51.35 \\
\hline $\begin{array}{l}\text { Atrazine } 50 \text { WP @0.5 kg a.i./ha PE } \\
\text { fb 2,4-D ester @ } 500 \mathrm{~g} \text { a.i./ha PoE }\end{array}$ & 68.10 & 8.21 & 27.48 & 103.80 & 103.33 & 10.97 & 37.33 & 151.63 & 52.24 & 96.03 & 54.75 & 73.81 \\
\hline $\begin{array}{l}\text { Halosulfuron } 75 \text { G@60g a.i./ha } \\
\text { PoE }\end{array}$ & 61.85 & 55.93 & 8.54 & 126.32 & 103.33 & 95.67 & 8.33 & 207.33 & 52.41 & 65.41 & 90.02 & 64.14 \\
\hline $\begin{array}{l}\text { Atrazine 50WP @0.5 kg a.i./ha PE } \\
\text { fb Halosulfuron 75G@60g a.i./ha } \\
\text { PoE }\end{array}$ & 50.90 & 47.31 & 1.85 & 100.06 & 65.00 & 83.67 & 3.69 & 152.36 & 70.31 & 69.73 & 95.45 & 73.70 \\
\hline $\begin{array}{l}\text { Tembotrione } 42 \text { SC@ } 120 \text { g a.i./ha } \\
\text { PoE }\end{array}$ & 17.67 & 14.00 & 4.03 & 35.70 & 25.33 & 13.00 & 7.60 & 45.93 & 88.33 & 95.34 & 90.56 & 92.07 \\
\hline $\begin{array}{l}\text { Atrazine 50WP @0.5 kg a.i./ha PE } \\
\text { fb Tembotrione } 42 \text { SC@ } 120 \mathrm{~g} \\
\text { a.i./ha PoE }\end{array}$ & 9.39 & 7.48 & 3.27 & 20.14 & 10.00 & 6.33 & 3.00 & 20.00 & 95.09 & 97.71 & 96.27 & 96.54 \\
\hline $\begin{array}{l}\text { Tompramezone } 33.6 \text { SC @ } 25.2 \text { g } \\
\text { a.i./ha PoE }\end{array}$ & 68.00 & 50.00 & 14.11 & 132.11 & 119.00 & 92.33 & 19.67 & 231.00 & 45.20 & 66.72 & 76.46 & 60.15 \\
\hline $\begin{array}{l}\text { Atrazine 50WP @0.5 kg a.i./ha PE } \\
\text { fb tompramezone } 33.6 \mathrm{SC} @ 25.2 \mathrm{~g} \\
\text { a.i./ha PoE }\end{array}$ & 52.67 & 45.00 & 11.33 & 109.00 & 86.00 & 83.67 & 15.33 & 185.00 & 60.20 & 69.82 & 81.12 & 68.02 \\
\hline $\operatorname{LSD}(\mathbf{P}=0.05)$ & 10.39 & 10.55 & 3.81 & 18.05 & 22.02 & 16.49 & 6.89 & 27.81 & 8.41 & 6.06 & 5.6 & 2.97 \\
\hline
\end{tabular}

fb-followed by, PE- Pre-emergence, PoE-Post-emergence, a.i.- Active ingredient 
Table.3 Effect of weed management on growth and yield attributes, grain yield and economic of maize (pooled data of two years)

\begin{tabular}{|c|c|c|c|c|c|c|c|c|c|}
\hline Treatment & $\begin{array}{c}\text { No of } \\
\text { plant } \\
(000 / h a)\end{array}$ & $\begin{array}{c}\text { Plant } \\
\text { height } \\
(\mathrm{cm})\end{array}$ & $\begin{array}{l}\text { No of cobs } \\
(000 / h a)\end{array}$ & $\begin{array}{c}\text { No of } \\
\text { grains/cob }\end{array}$ & $\begin{array}{l}\text { Grain yield } \\
\text { (t/ha) }\end{array}$ & $\begin{array}{l}\text { Weed } \\
\text { index }\end{array}$ & $\begin{array}{l}\text { Gross } \\
\text { return } \\
(\$ / h a)\end{array}$ & $\begin{array}{l}\text { Net return } \\
\quad \text { (\$/ha) }\end{array}$ & B:C ratio \\
\hline Weedy check & 55.56 & 210 & 47.2 & 268 & 4.96 & 58.07 & 1081 & 593 & 1.21 \\
\hline Weed free & 82.87 & 283 & 106.0 & 651 & 12.65 & 0.00 & 2755 & 2011 & 2.70 \\
\hline $\begin{array}{l}\text { Atrazine 50WP @0.5 kg } \\
\text { a.i./ha PE }\end{array}$ & 70.37 & 250 & 63.4 & 389 & 7.16 & 45.91 & 1560 & 1051 & 2.07 \\
\hline $\begin{array}{l}\text { Atrazine 50WP @0.5 kg } \\
\text { a.i./ha PE fb 2,4-D ester } \\
\text { @ 500g a.i./ha PoE }\end{array}$ & 77.78 & 268 & 70.4 & 460 & 8.57 & 31.28 & 1866 & 1321 & 2.42 \\
\hline $\begin{array}{l}\text { Halosulfuron 75G@60g } \\
\text { a.i./ha PoE }\end{array}$ & 57.41 & 230 & 51.9 & 409 & 7.63 & 50.87 & 1662 & 1070 & 1.81 \\
\hline $\begin{array}{l}\text { Atrazine 50WP @0.5 kg } \\
\text { a.i./ha PE fb Halosulfuron } \\
\text { 75G@60g a.i./ha PoE }\end{array}$ & 68.52 & 241 & 54.6 & 452 & 8.31 & 46.88 & 1810 & 1198 & 1.96 \\
\hline $\begin{array}{l}\text { Tembotrione } 42 \text { SC@ } 120 \text { g } \\
\text { a.i./ha PoE }\end{array}$ & 81.48 & 279 & 83.3 & 554 & 10.40 & 23.35 & 2266 & 1700 & 3.00 \\
\hline $\begin{array}{l}\text { Atrazine 50WP @0.5 kg } \\
\text { a.i./ha PE fb Tembotrione } \\
\text { 42 SC@120 g a.i./ha PoE }\end{array}$ & 83.33 & 282 & 106.0 & 639 & 12.26 & 0.36 & 2671 & 2085 & 3.55 \\
\hline $\begin{array}{l}\text { Tompramezone } 33.6 \mathrm{SC} \\
\text { @ } 25.2 \text { g a.i./ha PoE }\end{array}$ & 62.96 & 248 & 57.9 & 398 & 7.19 & 45.34 & 1567 & 1001 & 1.77 \\
\hline $\begin{array}{l}\text { Atrazine 50WP @0.5 kg } \\
\text { a.i./ha PE fb tompramezone } \\
\text { 33.6 SC @ 25.2 g a.i./ha PoE }\end{array}$ & 64.81 & 270 & 62.5 & 427 & 7.73 & 42.20 & 1685 & 1098 & 1.87 \\
\hline LSD $(\mathbf{P}=\mathbf{0 . 0 5})$ & 12.23 & 13.12 & 9.73 & 86.17 & 1.71 & & 373 & 373 & 0.66 \\
\hline
\end{tabular}

fb-followed by, PE- Pre-emergence, PoE-Post-emergence, a.i.- Active ingredient, 
Fig.1 Graphical presentation of temperature, precipitation and maximum relative humidity during crop season (November 2016 to April 2017)

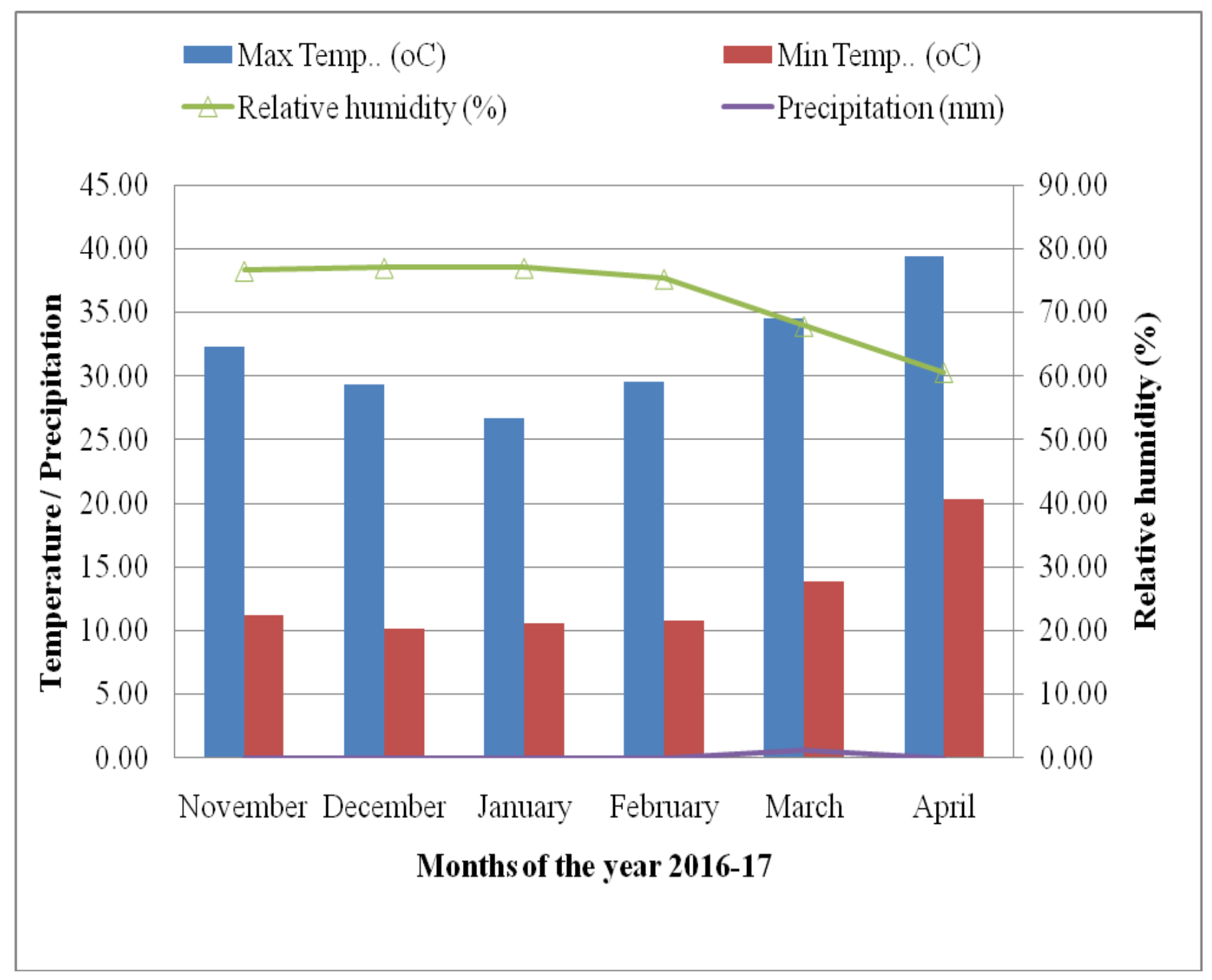


Fig.2 Graphical presentation of temperature, precipitation and maximum relative humidity during crop season (November 2017 to April 2018)

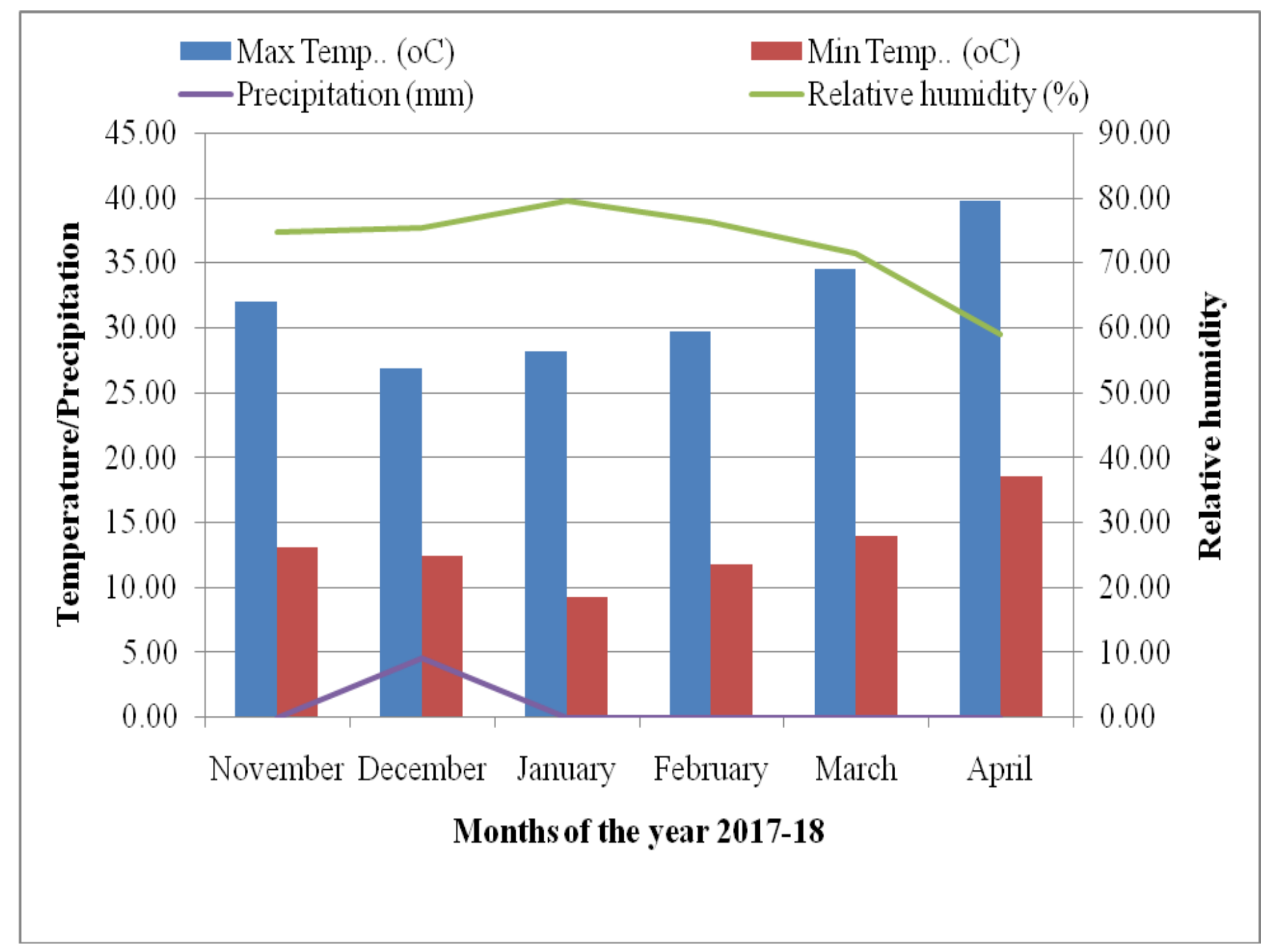


Int.J.Curr.Microbiol.App.Sci (2019) 8(7): 734-746

Fig.3 Relationship between weed biomass at 60 DAS and grain yield of winter maize

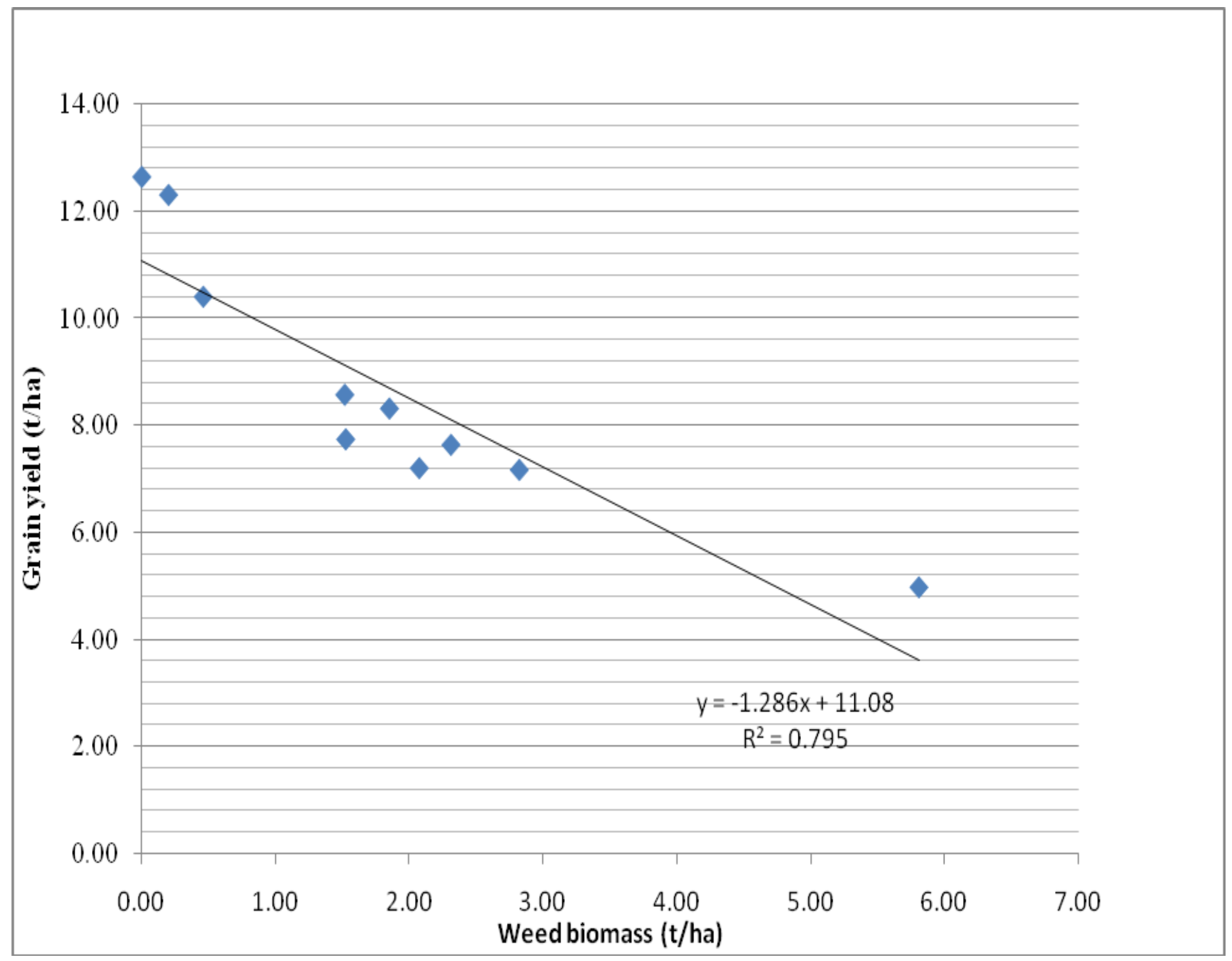




\section{Grain yield}

The highest grain yield (12.65 t/ha) was recorded in weed free plot which was at par with pre-emergence application of atrazine 50 WP @ $0.50 \mathrm{~kg}$ a.i./ha fb post-emergence application of tembotrione 42 SC @ $120 \mathrm{~g} / \mathrm{ha}$ and significantly higher than rest treatments (Table 3). Post-emergence application of tembotrione 42 SC @ $120 \mathrm{~g}$ a.i./ha at 35 DAS gave $10.40 \mathrm{t} / \mathrm{ha}$ grain yield which recorded next best treatment among herbicidal treatments.

Pre-emergence application of atrazine $50 \mathrm{WP}$ @ $0.50 \mathrm{~kg}$ a.i./ha $\mathrm{fb}$ post-emergence application of 2,4-D ester @ $500 \mathrm{~g}$ a.i./ha at 35 DAS gave 8.57 t/ha grain yield, which was at par with all herbicidal treatments. However, it was $72.78 \%$ significantly higher over weedy check (4.96 t/ha). Triveni et al., (2017) reported that the highest green cob yield, fodder yield in twice hand weeding at 20 and 40 DAS which was at par with preemergence application of atrazine @ $1000 \mathrm{~g} / \mathrm{ha}$ followed by post-emergence application of tembotrione 42 SC @ $120 \mathrm{~g} / \mathrm{ha}$ and similar results also reported by Hargilas (2017). The study indicated that maize needs a longer weed free period for realizing the highest grain yield.

\section{Relationship between weed biomass and grain yield}

Correlation and regression analysis indicated that there was a significant negative linear relationship between grain yield and weed dry biomass. In regression analysis the eq. $\mathrm{Y}=$ $1.286 \mathrm{x}+11.08$ (Fig. 3) was found to be fit for the grain yield of maize and weed dry biomass, which was obtained from 60 DAS, where $\mathrm{Y}$ is grain yield and $\mathrm{x}$ is biomass. The results indicated that as the weed biomass increased, the grain yield of maize was decreased as a significant correction $\left(\mathrm{R}^{2}=\right.$
$0.795)$ at 60 DAS between grain yield of maize and weed dry biomass was observed. A negative correlation observed between grain yield of maize and weed dry biomass in the linear regression model. The regression model explained about $80 \%$ of the variation in grain yield due to weed biomass.

\section{Economic assessment}

With respect to economics (Table 3), the highest cost of cultivation was incurred in two manual hand hoeing and weeding at 20 and 40 DAS and one manual hand weeding at 60 DAS (\$744/ha) to keep weed free crop. Among, the herbicidal treatments, maximum cost of cultivation was $\$ 612 /$ ha incurred in pre-application of atrazine 50 WP @ $0.50 \mathrm{~kg}$ a.i./ha fb post-emergence application of halosulfuron75 WG @ $60 \mathrm{~g}$ a.i./ha which was similar to alone halosulfuron 75 WG @ $60 \mathrm{~g}$ a.i./ha (\$592/ha).Cost of cultivation was incurred in atrazine $50 \mathrm{WP} @ 0.50 \mathrm{~kg}$ a.i./ha fb topramezone 33.6 SC @ 25.2 g a.i./ha at 35 DAS (\$587/ha), alone topramezone 33.6 SC @ $25.2 \mathrm{~g}$ a.i./ha at 35 DAS (\$566/ha), cost of cultivation of tembotrione was recorded equal to topramezone as alone and along with atrazine, respectively.

Atrazine fb 2,4-D ester @ 500 g a.i./ha incurred \$ 545 and alone atrazine incurred \$ 509 and minimum cost of cultivation recorded in weedy check plot.

Maximum gross return (\$2755/ha) was recorded in weedy free plot which was at par with pre-emergence application of atrazine 50 WP @ $0.50 \mathrm{~kg}$ a.i./ha fb post emergence application of tembotrione 42 SC @ $120 \mathrm{~g}$ a.i./ha at 35 DAS and significantly higher than rest treatments. Post-emergence application of tembotrione 42 SC @120 g a.i./ha at 35 DAS was gave next best gross retrun (\$2281/ha) which was significantly higher over sequential application of atrazine as $\mathrm{PE} \mathrm{fb}$ 2,4-D ester, halosulfuron and 
topramezone $\mathrm{PoE}$ and alone post-emergence application of halosulfuron and topramezone and pre emergence application of atrazine. Preemergence application of atrazine $\mathrm{fb}$ post emergence application of 2,4-D ester gave gross return $(\$ 1866 / \mathrm{ha})$ followed by atrazine $\mathrm{PE} \mathrm{fb}$ topramezone $\mathrm{PoE}$ and atrazine $\mathrm{PE} \mathrm{fb}$ halosulfuron PoE. Whereas, significant variations were not observed between sequential application of atrazine PE fb 2,4-D ester, halosulfuron and topramezone $\mathrm{PoE}$ and alone application of atrazine PE, holosulfuron PoE and topramezone PoE, respectively.

Maximum net return (\$ 2095/ha) was recorded in pre-emergence application of atrazine $50 \mathrm{WP}$ @ $0.50 \mathrm{~kg}$ a.i./ha fb post-emergence application of tembotrione 42 SC @ $120 \mathrm{~g}$ a.i./ha at 35 DAS which was at par with weed free plot and significantly higher over rest treatments. Postemergence application of tembotrione42 SC @ $120 \mathrm{~g}$ a.i./ha was found significantly higher net return (\$1700/ha) than the sequential application of atrazine as PE fb 2,4-D ester, halosulfuron and topramezone $\mathrm{PoE}$ and alone atrazine PE and halosulfuron and topramezone PoE, respectively. Pre-emergence application of atrazine $\mathrm{PE} \mathrm{fb}$ post-emergence application of 2,4-D ester was found higher net return (\$1321/ha) followed by atrazine $\mathrm{PE} \mathrm{fb}$ topramezone as $\mathrm{PoE}$ and atrazine $\mathrm{PE} \mathrm{fb}$ halosulfuron PoE, however, significant variation was not recorded and all herbicidal treatments were significantly higher than weedy check (\$593/ha).

Maximum benefit: cost ratio (3.57) was recorded in pre-emergence application of atrazine 50 WP @ $0.50 \mathrm{~kg}$ a.i./ha fb postemergence application of tembotrione 42 SC @ $120 \mathrm{~g}$ a.i./ha at $35 \mathrm{DAS}$ which was at par with alone post-emergence application of tembotrione 42 SC @ $120 \mathrm{~g}$ a.i./ ha at 35 DAS, however, it was recorded significantly superior over rest treatments. The $\mathrm{B}: \mathrm{C}$ ratio (2.70) was recorded in weed free plot which was at par with atrazine as PE fb 2,4-D ester PoE (2.42), atrazine PE fb topramezone PoE (2.09) and alone atrazine PE (2.07), respectively. However, it was significantly higher over sequential application of atrazine as PE fb halosulfuron as PoE (1.75) and alone topramezon PoE (1.93) and alone halosulfuron as PoE (1.65).

The minimum B: C ratio (1.21) was recorded in the weedy check (1.21). Dey et al., (2018) also reported that the highest net return and $\mathrm{B}$ : C ratio was observed in pre-emergence application of atrazine followed by post-emergence application of tembotrione.

The study concluded that pre-emergence application of atrazine $50 \mathrm{WP} @ 0.50 \mathrm{~kg}$ a.i./ha followed by post-emergence application of tembotrione 42 SC @120 g a.i./ha at 35 DAS was proved to effective weed management treatment among all weed control treatments in weed control efficiency, grain yield and economic return.

Post-emergence application of halosufuron 75WG@60 g a.i./ha showed the phyto-toxic effect on crop plants to kill and reduced plant growth. Post-emergence application of tembotrione did not show adverse effect on maize and next succeeding crop soybean.

Therefore, the sequencial application of atrazine 50 WP @ $0.50 \mathrm{~kg}$ a.i./ha PE followed by tembotrione 42 SC @ $120 \mathrm{~g}$ a.i./ha PoE at 35 DAS can be recommenced to winter maize based cropping system in the humid zone of Southern Rajasthan.

\section{Compliance with ethical standards}

Conflict of interest the author declares that there is no conflict of interest regarding the publication of this paper.

\section{References}

Anonymous (2019). Agricultural statistics at a glance 2019, Directorate of Economics and Statistics, Department of Agriculture, Cooperation and Farmers Welfare, Government of India, New Delhi. 
Chikoye, D., Schulz, S. and Ekeleme, F. (2004). Evaluation of integrated weed management practices for maize in the northern Guinea savanna of Nigeria. Crop Protection 23: 895-900.

Chikoye, D., Udensi, U.E., Fontem, A. and Lum (2005). Evaluation of a new formulation of atrazine and metolachlor mixture for weed control in maize in Nigeria. Crop Protection, 24, 1016-1020.

Dey, Prithwiraj, Pratap, Tej, Singh, V. P., Singh, Rohitashav and Singh, S.P. (2018). Weed management options in spring sweet corn (Zea mays L. Saccharata). International Journal of Chemical Studies, 6, 647-650.

GoI. (2015-16). Directorate of Economics and Statistics, Ministry of Agriculture, Government of India. http://eands.dacnet.nic.in/StateData_1516Year.htm

Gomez, K. A., Gomez, A. A. (1984).Statistical procedures for agricultural research. John Wiley and Sons.

Hargilas (2017). Evaluation of new herbicides to control weed flora and enhance the profitability of maize in Southern Rajasthan.(In) ISWS Biennial Conference on 'Doubling Farmers' Income by 2022: The Role of Weed Science", 1-3 March 2017, MPUAT, Udaipur.

Hargilas (2018). Evaluation of effective weed management strategy for enhancing productivity and profitability of chickpea (Cicer arietinum L.) under rain-fed condition of Southern Rajasthan. International Journal of Current Microbiology and Applied Sciences, $11,472-480$
Martin, M., Williams, II, Boydston, R. A., Peachey, Red and Robinson, D. (2011). Significance of atrazine as a tank-mix partner with tembotrione. Weed Technology, 25, 299-302.

Sharma, V. and Thakur, D.R. (1998). Integrated weed management in maize (Zea mays) under mid hill condition of NorthWestern Himalayas. Indian Journal of Weed Science, 30, 158-162.

Singh, S. and Sheoran, P. (2008). Studies on integrated weed management practices in rain fed maize under sub - mountainous conditions. Indian Journal of Dryland Agriculture Research and Development, 23, 6-9.

Singh, V.P., Guru, S.K., Kumar, A., Banga, A., and Tripathi, N. (2012). Bioefficacy of tembotrione against mixed weed complex in maize. Indian Journal of Weed Science, $44,1-5$.

Swetha, K., Madhavi, M., Pratibha, G. and Ramprakash, T. (2015). Weed management with new generation herbicides in maize. Indian Journal of Weed Science, 47, 432-433.

Triveni, U., Sandhya Rani, Y., Patro, T.S.S.K. and Bharathalakshmi, M. (2017). Effect of different pre and post-emergence herbicides on weed control, productivity and economics of maize. Indian Journal of Weed Science 49, 231-235.

Verma, V. K., Tewari, A. N. and Dhemri, S. (2009). Effect of atrazine on weed management in winter maize-green gram cropping system in central plain zone of Uttar Pradesh. Indian Journal of Weed Science, 41, 41-45.

\section{How to cite this article:}

Hargilas. 2019. Effective Weed Management Strategy for Winter Maize (Zea mays L) under Humid Condition of Southern Rajasthan. Int.J.Curr.Microbiol.App.Sci. 8(07): 734-746. doi: https://doi.org/10.20546/ijcmas.2019.807.089 